(C) The Author(s) 2019. This is an Open Access article, distributed under the terms of the Creative Commons Attribution licence (http:// creativecommons.org/licenses/by/4.0/), which permits unrestricted re-use, distribution, and reproduction in any medium, provided the original work is properly cited.

\title{
Modulation of growth hormone receptor-insulin-like growth factor 1 axis by dietary protein in young ruminants
}

\author{
Caroline S. Firmenich ${ }^{1}$, Nadine Schnepel ${ }^{1}$, Kathrin Hansen ${ }^{1}$, Marion Schmicke ${ }^{2}$ \\ and Alexandra S. Muscher-Banse ${ }^{1 *}$ \\ ${ }^{1}$ Institute for Physiology and Cell Biology, University of Veterinary Medicine Hannover, 30173 Hannover, Germany \\ ${ }^{2}$ Clinic for Cattle, Endocrinology Laboratory, University of Veterinary Medicine Hannover, 30173 Hannover, Germany
}

(Submitted 9 July 2019 - Final revision received 12 November 2019 - Accepted 13 November 2019 - First published online 28 November 2019)

\section{Abstract}

A reduced protein intake causes a decrease in insulin-like growth factor 1 (IGF1) concentrations and modulates Ca homoeostasis in young goats. IGF1 is synthesised by the liver in response to stimulation by growth hormone (GH). Due to rumino-hepatic circulation of urea, ruminants are suitable for investigating the effects of protein reduction despite sufficient energy intake. The present study aimed to investigate the impact of a protein-reduced diet on the expression of components of the somatotropic axis. Male young goats were divided into two feeding groups receiving either a control diet (20\% crude protein $(\mathrm{CP})$ ) or a reduced-protein diet $(9 \% \mathrm{CP})$. Blood concentrations of IGF1 and GH were measured, and a 24-h GH secretion profile was compiled. Moreover, ionised Ca and insulin concentrations as well as mRNA and protein expression levels of hepatic proteins involved in GH signalling were quantified. Due to the protein-reduced diet, concentrations of ionised Ca, insulin and IGF1 decreased significantly, whereas GH concentrations remained unchanged. Expression levels of the hepatic GH receptor (GHR) decreased during protein reduction. GHR expression was down-regulated due to diminished insulin concentrations as both parameters were positively correlated. Insulin itself might be reduced due to reduced blood Ca levels that are involved in insulin release. The protein-reduced diet had an impact on the expression of components of the somatotropic axis as a disruption of the GH-IGF1 axis brought about by diminished GHR expression was shown in response to a protein-reduced diet.

Key words: Growth hormone receptor: Insulin-like growth factor 1 synthesis: Insulin: Reduced-protein diet: Ruminants

In intensive livestock farming, feeding ruminants a dietary protein content close to their demand $\left(11-12 \%\right.$ crude protein $\left.^{(1)}\right)$ is preferable for economic and environmental reasons. Due to efficient rumino-hepatic circulation of urea ${ }^{(2)}$, ruminants are thought to easily cope with a reduced protein and therefore diminished $\mathrm{N}$ intake as long as the energy supply is maintained $\mathrm{d}^{(3)}$

However, it was shown that decreased dietary protein intake caused massive changes in mineral homoeostasis and vitamin D metabolism in young goats ${ }^{(4,5)}$; this being reflected by reduced levels of blood $\mathrm{Ca}, 1,25$-dihydroxyvitamin $\mathrm{D}_{3}$ (calcitriol) and insulin-like growth factor 1 (IGF1). Protein restriction was also shown to have an impact on Ca homoeostasis, IGF1 and vitamin $\mathrm{D}$ metabolism in monogastric species like humans and rats $^{(6-8)}$.

Calcitriol is synthesised by the action of mitochondrial enzyme $1 \alpha$-hydroxylase (CYP27B1) in the kidney ${ }^{(9)}$. IGF1 has a direct stimulating effect on the synthesis of calcitriol by modulating the expression and activity of renal CYP27B1 $1^{(10)}$.
A positive correlation between IGF1 concentration and CYP27B1 expression was shown, underlining the impact of IGF1 on CYP27B1 synthesis and therefore circulating levels of calcitriol $^{(11)}$.

Therefore, it was assumed that IGF1 was the link between reduced dietary protein intake and diminished levels of calcitriol and blood $\mathrm{Ca}$ in the present animals ${ }^{(12)}$. IGF1 is synthesised by the liver after pulsatile secretion of growth hormone $(\mathrm{GH})$ from the pituitary gland. The synthesis and secretion of $\mathrm{GH}$ are regulated by the hypothalamus, stimulated by GH-releasing hormone and inhibited by somatostatin ${ }^{(13)}$. GH mediates its action by binding to the membranous hepatic GH receptor (GHR) dimer and therefore initiates the Janus kinase-signal transducers and activators of transcription (JAK-STAT) pathway, leading to IGF1 secretion among others ${ }^{(14)}$. Through activating JAK2, GH is known to activate STAT 1,3 and $5^{(15)}$. Suppressor of cytokine signalling 1 (SOCS1) was shown to inhibit the

Abbreviations: ALS, acid-labile subunit; BW, body weight; CYP27B1, $1 \alpha$-hydroxylase; ERK1/2, extracellular signal-regulated kinases 1/2; FGF21, fibroblast growth factor 21; GH, growth hormone; GHR; GH receptor; IGF1, insulin-like growth factor 1; IGFBP, IGF1 binding protein; JAK-STAT, Janus kinase-signal transducers and activators of transcription; SOCS1, suppressor of cytokine signalling 1; Src, tyrosine-protein kinase src. 
concentrations of IGF1. The plasma and serum samples were stored at $-20^{\circ} \mathrm{C}$ for subsequent analysis.

Plasma GH and serum IGF1 concentrations were analysed in the Clinic for Cattle, Endocrinology Laboratory, University of Veterinary Medicine, Hannover, using in-house enzyme-linked immunosorbent assay or by RIA (Beckman Coulter).

\section{Blood sampling and biochemical determinations of blood parameters}

Blood samples were always collected at the same time in the morning before slaughtering to avoid circadian effects by puncturing the vena jugularis with EDTA-coated, lithium heparincoated syringes and serum syringes (Sarstedt AG \& Co. KG). Blood was separated by centrifugation (see above). Plasma and serum samples were stored at $-20^{\circ} \mathrm{C}$.

Plasma concentrations of urea were measured using a commercial kit (R-Biopharm AG). Ionised Ca and glucose concentrations were measured in whole blood samples. For the determination of ionised $\mathrm{Ca}$, an ion-sensitive electrode (Chiron Vaccines \& Diagnostics $\mathrm{GmbH}$ ) was used. Glucose levels were detected via the method of mutant Q-GDH-based blood glucose monitor using an Accu-Chek Performa glucose metre (Roche Diagnostic GmbH). Plasma concentrations of insulin were measured by ELISA, and triiodothyronine (T3) concentrations were analysed by competitive chemiluminescence immunoassay in the Clinic for Cattle, Endocrinology Laboratory, University of Veterinary Medicine, Hannover. Plasma concentrations of total protein were detected using a bromocresol green albumin assay kit (Sigma-Aldrich Chemie GmbH). Serum concentrations of TAG were measured in the Clinic for Cattle, Chemical and Clinical Laboratory, University of Veterinary Medicine, Hannover. Protein expressions of IGFBP2, IGFBP3, IGFBP4 and IGFBP5 in plasma were analysed commercially by quantitative Western ligand blot analysis as previously described (Ligandis) ${ }^{(22)}$. The measurements of serum IGF1 and plasma GH concentrations in samples were taken before slaughtering as previously explained.

\section{Hepatic tissue sampling and histological slices}

At the end of the experimental feeding after 6 weeks, the goats were slaughtered after captive bolt stunning by exsanguination. To avoid circadian effects, slaughtering was always performed at the same time in the morning. For technical reasons, four goats per d were killed from an alternating group. On one day, five goats were killed.

Liver samples were removed within 5 min post-mortem and immediately rinsed with ice-cold saline $(0.9 \% \mathrm{NaCl})$, frozen in liquid $\mathrm{N}_{2}$ and stored at $-80^{\circ} \mathrm{C}$ until further preparation. To assess the texture of the hepatic tissue, histological slices were made and dyed with haematoxylin-eosin as previously described using a standard procedure ${ }^{(23)}$. Moreover, Sudan stains were made by the Department of Pathology, University of Veterinary Medicine, Hannover to determine the level of fat in liver tissue as previously described ${ }^{(23)}$.

\section{Gene expression analysis}

Total RNA was isolated using the RNeasy plus Mini Kit (Qiagen) with genomic DNA eliminator spin columns in accordance with the manufacturer's protocol. The RNA concentrations were measured by UV-visible spectrophotometry (Thermo Fisher Scientific GmbH, NanoDrop One). To verify the quality of the isolated RNA, the RNA integrity number was evaluated with an RNA 6000 nanoassay for an Agilent 2100 Bioanalyzer (Agilent Technologies GmbH).

Using random hexamers, oligo-dT primers and TaqMan Reverse-Transcription Reagents (Applied Biosystems Deutschland $\mathrm{GmbH}$ ), 200 ng isolated hepatic RNA was reversetranscribed in accordance with the manufacturer's protocol. The primers used for the production of recombinant DNA were derived either from caprine, ovine or bovine sequences. Primers were designed to span exon-exon junctions. The GHR1A primer pair was designed to amplify the most common variance of the hepatic $\mathrm{GHR}^{(24)}$. Primer sequences, exon spanning region, amplicon length and efficiency are summarised in Table 2. Expressions of hepatic ALS, ERK2, FGF21, GHR1A, IGF1, IGFBP2, IGFBP3, INSR, JAK2, RPS9, SOCS1, SOCS2, SOCS3 and STAT5B were determined using SYBR Green PCR assays. Reaction mixtures $(20 \mu \mathrm{l})$ contained KAPA SYBR FAST Universal Master Mix (PEQLAB Biotechnology GmbH), $200 \mathrm{~nm}$ specific primers and $16 \mathrm{ng}$ reverse-transcribed complementary DNA (cDNA). PCR products were amplified $\left(95^{\circ} \mathrm{C}, 3 \mathrm{~min}\right.$; forty cycles of $95^{\circ} \mathrm{C}, 10 \mathrm{~s}$ and $60^{\circ} \mathrm{C}, 30 \mathrm{~s}$ ). Primer sequences, exon spanning region, amplicon length and efficiency are summarised in Table 3. For quantifying the expressions of hepatic $18 \mathrm{~S}$ rRNA, $\beta$-actin and GAPDH mRNA, primers and probes were purchased from TIB MOLBIOL. Reaction mixtures $(20 \mu \mathrm{l})$ contained TaqMan

Table 2. Primers and probes used for TaqMan assays

\begin{tabular}{|c|c|c|c|c|c|c|}
\hline Gene & $\begin{array}{l}\text { Sense and antisense primers } \\
\left(5^{\prime} \rightarrow 3^{\prime}\right) \text {, probes }\end{array}$ & $\begin{array}{l}\text { Exon } \\
\text { location }\end{array}$ & $\begin{array}{l}\text { Amplicon } \\
\text { length (bp) }\end{array}$ & $\begin{array}{l}\text { Amplification } \\
\text { efficiency (\%) }\end{array}$ & $\begin{array}{l}\text { Accession } \\
\text { number }\end{array}$ & Source \\
\hline 18S rRNA & $\begin{array}{l}\text { AAAAATAACAATACAGGACTCTTTCG } \\
\text { GCTATTGGAGCTGGAATTACCG } \\
\text { FAM-TGGAATGAGTCCACTTTAAATCCTTCCGC-BBQ }\end{array}$ & - & 127 & 85 & KY129860 & $(11)$ \\
\hline$\beta$-Actin & $\begin{array}{l}\text { CTCAGAGCAAGAGAGGCATCC } \\
\text { GCAGCTCGTTGTAGAAGGTGTG } \\
\text { FAM-CAAGTACCCCATTGAGCACGGC-TMR }\end{array}$ & 3 & 111 & 99 & XM_018039831.1 & $(25)$ \\
\hline GAPDH & $\begin{array}{l}\text { CAAGGTCATCCATGACCACTTT } \\
\text { CGGAAGGGCCATCCACA } \\
\text { FAM-CTGTCCACGCCATCACTGCCACCC-TMR }\end{array}$ & $7-8$ & 95 & 100 & NM_001190390 & (26) \\
\hline
\end{tabular}

18S rRNA, 18S ribosomal RNA; GAPDH, glyceraldehyde 3-phosphate dehydrogenase. 
Table 3. Primers used for SYBR Green assays

\begin{tabular}{|c|c|c|c|c|c|c|}
\hline Gene & Sense and antisense primers $\left(5^{\prime} \rightarrow 3^{\prime}\right)$ & Exon location & $\begin{array}{l}\text { Amplicon } \\
\text { length (bp) }\end{array}$ & $\begin{array}{l}\text { Amplification } \\
\text { efficiency (\%) }\end{array}$ & Accession number & Source \\
\hline ALS & $\begin{array}{l}\text { TACCTGGACCACAACCTCGT } \\
\text { AGTGCAGGTCCTTGAAGGTG }\end{array}$ & 2 & 202 & 86 & XM_018040889.1 & $(27)$ \\
\hline ERK2 & $\begin{array}{l}\text { TCCCGAATGCTGACTCCAAA } \\
\text { CTTGGGCAAGTCATCCAAATACA }\end{array}$ & - & 185 & 86 & JQ308787.1 & Present study \\
\hline FGF21 & $\begin{array}{l}\text { CCTCTACACGGATGATGCCC } \\
\text { GCTTTGGGGTCAAAGTGCAG }\end{array}$ & $1-3$ & 216 & 100 & XM_005692688.3 & Present study \\
\hline GHR1A & $\begin{array}{l}\text { CGTCTCTGCTGGTGAAAACA } \\
\text { GGATGTCGGCATGAATCTCT }\end{array}$ & 4,5 & 203 & 101 & NM_176608.1 & $(22)$ \\
\hline IGF1 & $\begin{array}{l}\text { ATCAGCAGTCTTCCAACCCAAT } \\
\text { ACACACGAACTGGAGAGCATCC }\end{array}$ & 1,2 & 192 & 105 & XM_005680531.3 & Present study \\
\hline IGF2 & $\begin{array}{l}\text { TGGCCCTACTGGAGACCTAC } \\
\text { CACGGGGTATGCTGTGAAGT }\end{array}$ & 3,4 & 101 & 104 & NM_001287041.1 & Present study \\
\hline IGFBP2 & $\begin{array}{l}\text { GTCCTGGAACGGATCTCCAC } \\
\text { TCTTGCACTGTTTGAGGTTGT }\end{array}$ & 2,3 & 121 & 100 & NM_001314299.1 & Present study \\
\hline IGFBP3 & $\begin{array}{l}\text { GCATGAGACAGAATACGGGC } \\
\text { TCCACACACCAGCAGAAACC }\end{array}$ & $2-4$ & 183 & 106 & NM_001314219.1 & Present study \\
\hline INSR & $\begin{array}{l}\text { TATGGGACTGGGGCAAACAC } \\
\text { TTTCACAGGATGCCTGGTCC }\end{array}$ & 6,7 & 177 & 101 & XM_018051134.1 & Present study \\
\hline JAK2 & $\begin{array}{l}\text { GTGCTGGCCGGCATAATCTA } \\
\text { ATTCCTTGTCGCCAGATCCC }\end{array}$ & $20-22$ & 188 & 101 & XM_018052022.1 & Present study \\
\hline RPS9 & $\begin{array}{l}\text { CGCCTCGACCAAGAGCTGAAG } \\
\text { CTCCAGACCTCACGTTTGTTCC }\end{array}$ & 2,3 & 65 & 73 & XM_018063497.1 & (28) \\
\hline SOCS1 & $\begin{array}{l}\text { CTCGTACCTCCTACCTCTTCATGTT } \\
\text { CACAGCAGAAAAATAAAGCCAGAGA }\end{array}$ & 2 & 95 & 99 & XM_864316.5 & $(28)$ \\
\hline socs2 & $\begin{array}{l}\text { CTTTGAAACAGCTGCGTCCC } \\
\text { AGCAGGCATGTATCCCCCTA }\end{array}$ & 3 & 163 & 95 & XM_018047627.1 & Present study \\
\hline socs3 & $\begin{array}{l}\text { AAGACCTTCAGCTCCAAGAGCG } \\
\text { AGCAGCAAGTTCGCTTCGC }\end{array}$ & 1 & 113 & 110 & XM_004013097.3 & Present study \\
\hline Src & $\begin{array}{l}\text { GGCTTCTACATCACCTCCCG } \\
\text { CCTTGAGTCTGCGGCTTAGA }\end{array}$ & 8,9 & 131 & 90 & $\begin{array}{l}\text { XM_018057837.1 to } \\
\text { XM_018057840.1 }\end{array}$ & Present study \\
\hline STAT1 & $\begin{array}{l}\text { TCTCTACCCGTCGTGGTGAT } \\
\text { CCAGCTCAGCACCTCTGAAA }\end{array}$ & 16,17 & 159 & 89 & XM_018061547.1 & Present study \\
\hline STAT3 & $\begin{array}{l}\text { GACCTGGAGACGCACTCATT } \\
\text { CACTTGATCCCACGTTCCGA }\end{array}$ & $14-16$ & 156 & 93 & NM_001314278.1 & Present study \\
\hline STAT5B & $\begin{array}{l}\text { GCCACAGATCAAGCAAGTGG } \\
\text { GGGGATCCACTGACTGTCCAT }\end{array}$ & $16-18$ & 247 & 104 & $\begin{array}{l}\text { XM_018065118.1 } \\
\text { XM_018065117.1 }\end{array}$ & Present study \\
\hline
\end{tabular}

ALS, acid-labile subunit; ERK2, extracellular-signal regulated-kinase 2; FGF21, fibroblast growth factor 21; GHR1A, growth hormone receptor 1A; IGF1, insulin-like growth factor 1; IGF2, insulin-like growth factor 2; IGFBP2, insulin-like growth factor binding protein 2; IGFBP3, insulin-like growth factor binding protein 3; INSR, insulin receptor; JAK2, Janus kinase 2; RPS9, ribosomal protein S9; SOCS1, suppressor of cytokine signalling 1; SOCS2, suppressor of cytokine signalling 2; SOCS3, suppressor of cytokine signalling 3; Src, tyrosineprotein kinase src; STAT1, signal transducers and activators of transcription 1; STAT3, signal transducers and activators of transcription 3; STAT5B, signal transducers and activators of transcription $5 \mathrm{~B}$.

Universal PCR Master Mix (Applied Biosystems), 300 nм specific primers, 100 nm specific probe and 16 ng cDNA. The PCR product was amplified $\left(50^{\circ} \mathrm{C}, 2 \mathrm{~min} ; 95^{\circ} \mathrm{C}, 10 \mathrm{~min}\right.$; forty cycles of $95^{\circ} \mathrm{C}$, $15 \mathrm{~s}$ and $60^{\circ} \mathrm{C}, 1 \mathrm{~min}$ ) and analysed using a real-time PCR cycler (CFX96 ${ }^{\mathrm{TM}}$; Bio-Rad Laboratories $\mathrm{GmbH}$ ). Absolute copy numbers were determined using calibration curves generated with cloned PCR fragment standards ${ }^{(26)}$. Specificity of the amplicons was verified by sequencing (Seqlab Microsynth $\mathrm{GmbH}$ ) and using NCBI Blast (http://blast.ncbi.nlm.nih.gov/Blast.cgi). Expressions of genes of interest were normalised to a quotient of $18 \mathrm{~S}$ rRNA/ $\beta$-actin as two constantly expressed housekeeping genes in liver tissue during the applied dietary treatment which was determined by using NormFinder software (https://moma.dk/normfindersoftware). Reactions were performed in duplicate and included no template water controls.

\section{Tissue protein extraction and Western blot analysis}

Hepatic cytosol was isolated as described elsewhere ${ }^{(26)}$. Hepatic crude membranes were prepared using a FastPrep-24 High
Speed Homogenizer (MP Biomedicals GmbH). Briefly, frozen hepatic tissue was agitated with zirconia balls in a $20 \mathrm{mmol} / \mathrm{l}$ TRIS buffer containing $250 \mathrm{mmol} / 1$ sucrose, $5 \mathrm{mmol} / \mathrm{l}$ EGTA and $5 \mathrm{mmol} / 1 \mathrm{MgSO}_{4} .7 \mathrm{H}_{2} \mathrm{O}$ at $\mathrm{pH} 7 \cdot 5$. Afterwards, phosphatase inhibitor cocktail tablets (cOmplete ULTRA, Roche) and protease inhibitor cocktail tablets (PhosSTOP, Roche) were added in accordance with the manufacturer's instructions on the day of extraction, followed by centrifugation (2000 $\boldsymbol{g}$ at $\left.4^{\circ} \mathrm{C}, 20 \mathrm{~min}\right)$. In the following step, the homogenate was centrifuged ( $40000 \boldsymbol{g}$ at $4{ }^{\circ} \mathrm{C}, 60 \mathrm{~min}$ ). The supernatant was removed, and the pellet was dissolved in a $\mathrm{pH} 7.4$ buffer containing $10 \mathrm{mmol} / \mathrm{l}$ TRIS and $150 \mathrm{mmol} / \mathrm{l} \mathrm{NaCl}$. Protein concentrations were measured with a commercial protein assay using Bradford reagent (Serva Electrophoresis GmbH). For pERK1/ 2, ERK1/2, JAK2, SOCS2, Src, STAT1, STAT3 and STAT5B, $20 \mu \mathrm{g}$ hepatic cytosol and for GHR and INSR, $20 \mu \mathrm{g}$ hepatic crude membranes were separated by $8 \cdot 1 \%$ SDS-PAGE and transferred onto nitrocellulose membranes (GE Healthcare Europe GmbH) using the Trans-Blot Turbo transfer system (Bio-Rad). The primary antibodies used were chosen due to their specificity for 
the particular caprine protein or species cross-reactivity for caprine or bovine target protein. Moreover, protein sequences were verified for their homology using NCBI Blast (http:// blast.ncbi.nlm.nih.gov/Blast.cgi). To ensure that no non-specific signal was detected, membranes were incubated only with the secondary antibody. For pERK1/2, ERK1/2, JAK2, SOCS2, INSR, Src, STAT1 and STAT3, membranes were blocked in TRIS-buffered saline containing $0 \cdot 1 \%$ Tween 20 and for GHR and STAT5B, membranes were blocked in PBS containing $0 \cdot 1 \%$ Tween 20 with $5 \%$ fat-free milk powder, respectively. For pERK1/2 and ERK1/2, the membranes were incubated overnight at $4^{\circ} \mathrm{C}$ with anti-pERK1/2 and ERK1/2 antibody (Cell Signaling Technology Europe B.V.). After detecting pERK1/2 antibody, membranes were treated with a $\mathrm{pH} 2 \cdot 0$ stripping buffer as described elsewhere ${ }^{(29)}$ and used again for ERK1/2 antibody detection. For detecting caprine GHR protein, two different antibodies were used: a commercial antibody (Santa Cruz Inc.) and a self-made antibody (Davids Biotechnology GmbH). The membranes were incubated overnight at $4^{\circ} \mathrm{C}$ with the commercial or with the self-made anti-GHR antibody. The self-made antibody was successfully pre-incubated with the corresponding antigenic peptide (data not shown). For detecting JAK2, SOCS2, Src, STAT1, STAT3, STAT5B and INSR protein, membranes were incubated overnight at $4^{\circ} \mathrm{C}$ with anti-JAK2 antibody (Cell Signaling), anti-SOCS2 antibody (Cell Signaling), anti-Src antibody (Cell Signaling), anti-STAT1 antibody (Cell Signaling), anti-STAT3 antibody (Cell Signaling), anti-STAT5B antibody (GeneTex Inc.) or with anti-INSR antibody (Santa Cruz), respectively. After washing, membranes were incubated with corresponding secondary anti-rabbit or anti-mouse horseradish peroxidase-conjugated antibody. The proteins were detected with a chemiluminescence system and the ChemiDoc MP (Bio-Rad). Densitometric measurements were performed using Image Lab 5.2.1 software (Bio-Rad). For semi-quantifying the proteins, values of the investigated proteins were normalised to the amount of applied total protein amounts per lane.

\section{Statistical analysis}

Sample size (minimum $n 7$ /group) was determined based on metabolic data from previous work ${ }^{(5)}$ with a statistical power of 0.8 and $\alpha$ error of $0 \cdot 05$. Data are given as means with their standard errors if not stated otherwise and number of animals $(n)$. All data were normally distributed. Comparisons of values between the two feeding groups were analysed by unpaired Student's $t$ test. To test for linear relationship between two variables, a simple correlation analysis with Pearson's correlation coefficient was calculated. All statistical analyses were performed using GraphPad Prism version 7.04 (GraphPad Software; www.graphPad.com). $P<0.05$ was set to be significant, and $P<0 \cdot 1$ was used to define trends.

\section{Results}

Intake, body weight and daily weight gain during reduced protein feeding

All animals were clinically healthy during the present study. Mean daily intakes of DM, concentrate, $\mathrm{N}$ and Ca were calculated
Table 4. Mean daily intake of DM, concentrate, nitrogen, calcium and feed efficiency of growing goats receiving a protein-reduced diet (Mean values with their standard errors)

\begin{tabular}{|c|c|c|c|c|c|}
\hline \multirow[b]{2}{*}{ Items } & \multicolumn{2}{|c|}{ Control $(n 8)$} & \multicolumn{2}{|c|}{$\begin{array}{l}\text { Reduced protein } \\
\qquad(n 9)\end{array}$} & \multirow[b]{2}{*}{$P$} \\
\hline & Mean & SEM & Mean & SEM & \\
\hline DM intake (g/d) & 567 & 6.87 & 536 & $22 \cdot 7$ & 0.18 \\
\hline Concentrate intake $(\mathrm{g} / \mathrm{d})$ & 419 & 8.32 & 406 & $21 \cdot 2$ & 0.58 \\
\hline Feed efficiency $(\mathrm{kg} / \mathrm{kg})$ & 0.79 & 0.02 & 0.76 & 0.02 & 0.26 \\
\hline$N$ intake $(g / d)$ & 14.5 & 0.23 & $6 \cdot 2$ & 0.30 & $<0.001$ \\
\hline Ca intake $(\mathrm{g} / \mathrm{d})$ & 5.15 & 0.10 & 5.05 & 0.26 & 0.74 \\
\hline
\end{tabular}

for each animal individually. Feed efficiency was calculated as the difference between the final and initial weight divided by the calculated feed intake during this period. DM, concentrate and $\mathrm{Ca}$ intake did not differ between the two groups. Feed efficiency was not different, while $\mathrm{N}$ intake was significantly reduced in the animals receiving the protein-reduced diet (Table 4). Daily energy supply remained within the range recommended by the Society of Nutrition Physiology (GfE) for young ruminating goat kids. The initial BW (control 15.3 (SEM 0.67) kg, reduced protein 15.6 (SEM 0.80$) \mathrm{kg} ; P=0.74$ ) and the final $\mathrm{BW}$ of the goats were not different due to any dietary intervention (control 23.6 (sem 0.38) kg, reduced protein 22.7 (SEM 1.09) kg; $P=0 \cdot 47)$. Daily weight gain during the period of experimental feeding was not affected by any diet and ranged from $0 \cdot 14$ to $0 \cdot 16$ (sEM 0.008) $\mathrm{kg} / \mathrm{d}$.

\section{4- $h$ growth hormone and insulin-like growth factor 1 profile during reduced protein feeding}

Concentrations of IGF1 were significantly diminished at all time points (11.00, 19.00 and 03.00 hours) due to the protein-reduced feeding (Table 5). The number of 24-h GH pulses blood sampling did not differ significantly between the two feeding groups. Moreover, total GH secretion during the time of blood sampling showed no significant differences due to any feeding regimen (Table 6).

\section{Blood parameters during reduced protein feeding}

The subsequent sections present the results of the different blood parameters for the two feeding regimens on the day of slaughter. Results are described in detail where differences between the groups occurred (Table 7). Plasma urea, concentrations of blood ionised Ca, serum IGF1 (Fig. 1(a)) and plasma insulin (Fig. 1(b)) concentrations decreased significantly when

Table 5. Effects of a reduced-protein diet on insulin-like growth factor 1 concentrations $(\mathrm{ng} / \mathrm{ml})$ in young goats (Mean values with their standard errors)

\begin{tabular}{lcccccc}
\hline & \multicolumn{3}{c}{} & & \multicolumn{3}{c}{ Reduced protein } \\
& \multicolumn{2}{c}{ Control $(n 8)$} & & & \\
\cline { 2 - 3 } Parameters & Mean & SEM & & Mean & SEM & $P$ \\
\hline 11.00 hours & 404 & 36.8 & & 257 & 23.6 & 0.005 \\
19.00 hours & 397 & $32 \cdot 1$ & & 279 & 27.0 & 0.014 \\
03.00 hours & 408 & $29 \cdot 8$ & & 299 & 22.3 & 0.011 \\
\hline
\end{tabular}


Table 6. Effects of a reduced-protein diet on growth hormone (GH) pulsatility given in number of pulses per $24 \mathrm{~h}$ and $\mathrm{GH}$ secretion given as total $\mathrm{GH}$ in $24 \mathrm{~h}$ in young goats

(Mean values with their standard errors)

\begin{tabular}{|c|c|c|c|c|c|}
\hline \multirow[b]{2}{*}{ Parameters } & \multicolumn{2}{|c|}{ Control ( $n$ 8) } & \multicolumn{2}{|c|}{$\begin{array}{l}\text { Reduced protein } \\
\qquad(n 8)\end{array}$} & \multirow[b]{2}{*}{$P$} \\
\hline & Mean & SEM & Mean & SEM & \\
\hline Number of pulses $<10$ & 51.88 & $7 \cdot 23$ & 54.38 & 7.9 & 0.59 \\
\hline Number of pulses $\geq 10$ & $20 \cdot 13$ & $7 \cdot 23$ & $26 \cdot 5$ & 7.87 & 0.59 \\
\hline $\begin{array}{l}\text { Total hormone secretion } \\
(\mathrm{ng} / \mathrm{ml} \text { per } 24 \mathrm{~h})\end{array}$ & $589 \cdot 18$ & 92.68 & $687 \cdot 75$ & 108.53 & 0.50 \\
\hline
\end{tabular}

Table 7. Effects of a reduced-protein diet on blood parameters of young goats (Mean values with their standard errors)

\begin{tabular}{|c|c|c|c|c|c|}
\hline \multirow[b]{2}{*}{ Items } & \multicolumn{2}{|c|}{ Control ( $n$ 8) } & \multicolumn{2}{|c|}{$\begin{array}{l}\text { Reduced protein } \\
\qquad(n 9)\end{array}$} & \multirow[b]{2}{*}{$P$} \\
\hline & Mean & SEM & Mean & SEM & \\
\hline \multicolumn{6}{|l|}{ Total blood } \\
\hline lonised $\mathrm{Ca}(\mathrm{mmol} / \mathrm{l})$ & $1 \cdot 27$ & 0.01 & $1 \cdot 20$ & 0.02 & 0.04 \\
\hline $\mathrm{pH}$ & 7.44 & 0.007 & 7.45 & 0.006 & 0.21 \\
\hline \multicolumn{6}{|l|}{ Plasma } \\
\hline Urea (mmol/l) & $5 \cdot 22$ & 0.41 & 0.86 & 0.09 & $<0.0001$ \\
\hline Insulin $(\mu \mathrm{U} / \mathrm{ml})$ & $25 \cdot 6$ & 3.6 & $12 \cdot 9$ & 1.98 & 0.006 \\
\hline Glucose $(\mathrm{mg} / \mathrm{dl})^{\star}$ & 76.5 & 1.45 & $73 \cdot 11$ & 1.98 & 0.20 \\
\hline Total protein $(\mathrm{mg} / \mathrm{ml})$ & 49.4 & $1 \cdot 15$ & $51 \cdot 3$ & $2 \cdot 01$ & 0.46 \\
\hline $\mathrm{GH}(\mathrm{ng} / \mathrm{ml})$ & $20 \cdot 2$ & $2 \cdot 0$ & $21 \cdot 3$ & 2.5 & 0.75 \\
\hline T3 (ng/ml) & 2.19 & $0 \cdot 12$ & 2.04 & 0.07 & 0.27 \\
\hline \multicolumn{6}{|l|}{ Serum } \\
\hline IGF1 (ng/ml) & 408 & 41.0 & 287 & 21.8 & 0.02 \\
\hline TAG (mmol/l) & 0.28 & 0.02 & 0.28 & 0.02 & 0.93 \\
\hline
\end{tabular}

GH, growth hormone; T3, triiodothyronine; IGF1, insulin-like growth factor 1 . * To convert glucose in $\mathrm{mg} / \mathrm{dl}$ to $\mathrm{mmol} / \mathrm{l}$, multiply by 0.0555 .

dietary protein was reduced. A significant positive correlation between blood ionised $\mathrm{Ca}$ and plasma insulin concentration was determined $(r$ 0.55, $P=0.02)$ and between plasma insulin and urea concentrations $(r 0.51, P=0 \cdot 04)$. Plasma concentration of IGFBP2 (Fig. 2(a)) and IGFBP3 (Fig. 2(b)) protein increased significantly due to the protein-reduced feeding. Plasma concentration of IGFBP 4 protein was not modulated by any dietary intervention (Fig. 2(c)). The plasma IGFBP5 protein concentration decreased by trend due to the proteinreduced feeding (Fig. 2(d)). A negative correlation between
IGFBP2 plasma protein concentrations and serum IGF1 concentration was detected $(r-0 \cdot 57, P=0 \cdot 02)$, whereas a positive correlation between IGFBP5 plasma protein concentration and serum IGF1 concentration was measured $(r 0 \cdot 78, P=0 \cdot 002)$. No significant correlation was detected between concentrations of IGFBP3 or IGFBP4 protein and serum levels of IGF1. For determining the amount of free IGF1, a quotient between IGF1 and IGFBP3 was calculated which was significantly reduced in the low-protein-fed group (Fig. 2(e), $P<0 \cdot 001$ ).

\section{Assessment of liver tissue}

Microscopic evaluations of the histological liver slices dyed with haematoxylin-eosin indicated no differences between the two feeding groups. The fat staining showed only a few small diffuse fatty vacuoles in both groups. Therefore, no accumulation of fat or hepatic damage was assumed (data not shown).

Expression of acid-labile subunit, extracellular signalregulated kinases 2, fibroblast growth factor 21 , growth hormone receptor $1 \mathrm{~A}$, insulin-like growth factor 1 , insulin-like growth factor 2, IGF1 binding protein 2, IGF1 binding protein 3, insulin receptor, Janus kinase 2, suppressor of cytokine signalling 1, suppressor of cytokine signalling 2, suppressor of cytokine signalling 3and signal transducers and activators of transcription 5BmRNA during reduced protein feeding

The integrity of the isolated RNA of all hepatic tissue samples, expressed as RNA integrity number, was at least 8.7 (SEM 0.04). The mRNA expression levels of ERK2, IGF2, IGFBP3, INSR, JAK2 and STAT5B showed no alternation due to the proteinreduced feeding. Furthermore, the mRNA expression of SOCS1 was not altered, whereas the mRNA expression levels of SOCS2 showed an increase by trend and SOCS3 mRNA expression was significantly enhanced in the protein-reducedfed animals. Expression levels of FGF21 and IGFBP2 increased significantly due to the low-protein feeding. The proteinreduced diet led to a significant decrease in ALS, IGF1 and GHR1A mRNA expression levels (Table 8). A significant positive correlation between GHR mRNA expression levels and plasma urea concentrations $(r 0.64, P=0.006)$, plasma insulin concentration $(r 0.61, P=0 \cdot 01)$ and between GHR mRNA expression and serum IGF1 concentration $(r 0 \cdot 64, P=0 \cdot 006)$ was detected. (a)

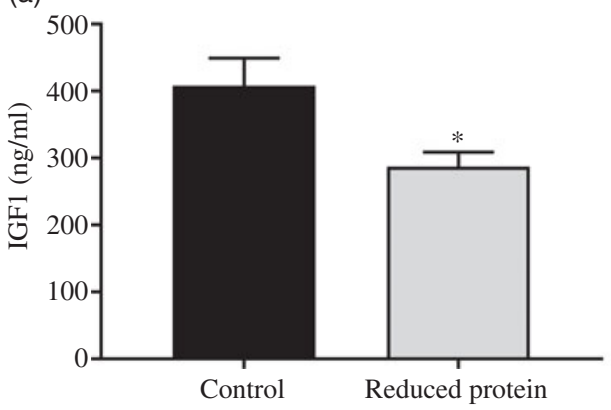

(b)

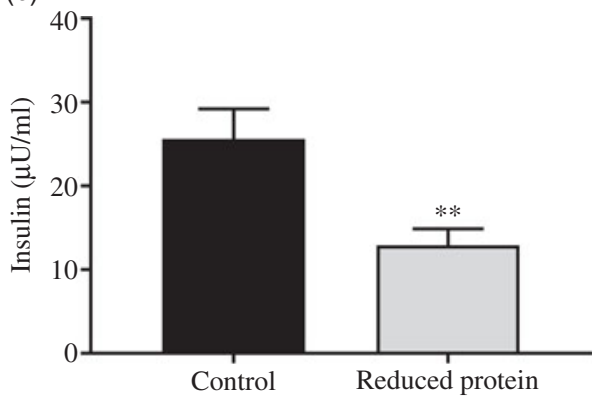

Fig. 1. Concentration of insulin-like growth factor 1 (IGF1) (a) and insulin (b) in plasma of goats receiving a protein-reduced diet. Data are expressed as mean values with their standard errors; control $=$ eight animals and reduced protein $=$ nine animals. ${ }^{*} P<0.05,{ }^{\star *} P<0.01 \mathrm{v}$. control diet. 
(a)

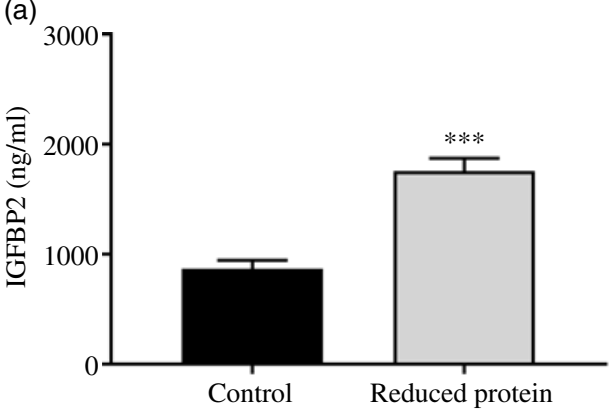

(c)

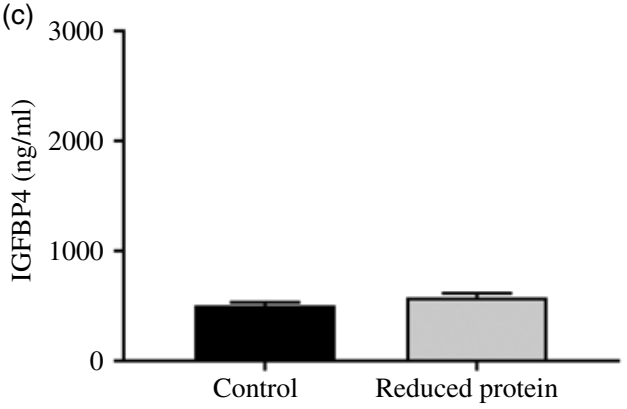

(b)
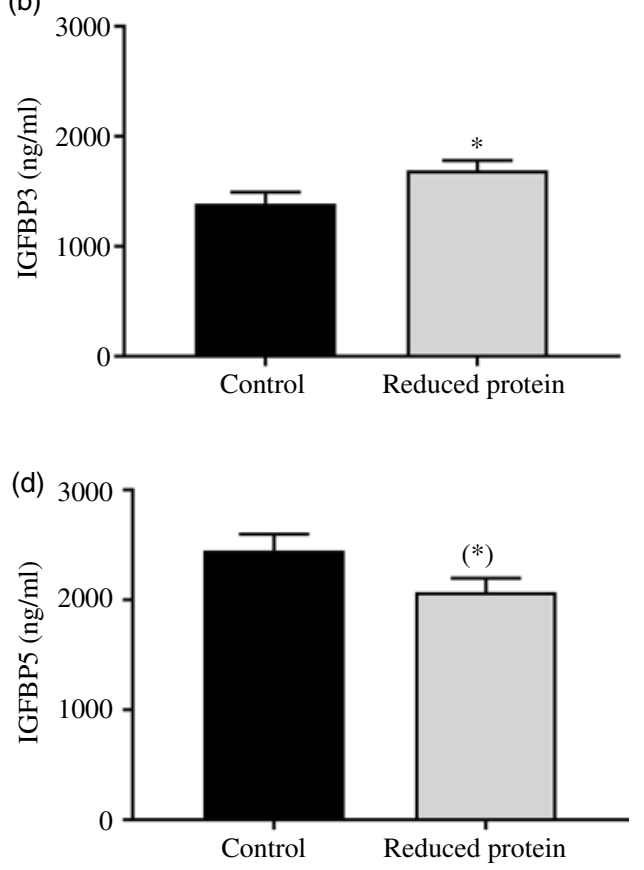

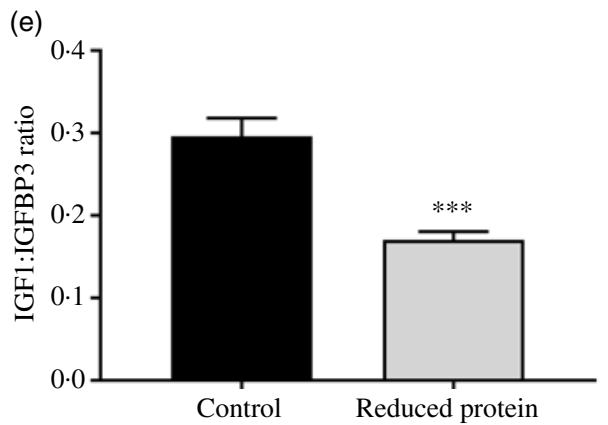

Fig. 2. Concentration of insulin-like growth factor 1 (IGF1) binding protein 2 (IGFBP2) (a), of IGFPB3 (b), of IGFBP4 (c), IGFPB5 (d) and of free IGF1 as a quotient of IGF1 and IGFBP3 (e) in plasma of goats receiving a protein-reduced diet. Data are expressed as mean values with their standard errors; control = eight animals and reduced protein $=$ nine animals. $\left({ }^{\star}\right) P<0.10,{ }^{*} P<0.05,{ }^{* \star *} P<0.001 \mathrm{v}$. control diet.

Expression of extracellular signal-regulated kinases 1/2, growth hormone receptor, insulin receptor, Janus kinase 2, suppressor of cytokine signalling 2, tyrosine-protein kinase src, signal transducers and activators of transcription 1, signal transducers and activators of transcription 3and signal transducers and activators of transcription 5Bprotein during reduced protein feeding

The ERK1/2 and pERK1/2 protein expression levels were detected as two bands of 42 and $44 \mathrm{kDa}$, respectively. Protein expression levels of EKR1/2 showed no significant differences due to the applied diets. Phosphorylation levels of EKR1/2 were not significantly different between the two feeding groups. Protein expression of GHR was detected as two bands of 110 and $140 \mathrm{kDa}$ in accordance with the manufacturer's instructions (Santa Cruz Biotechnology) and decreased significantly due to the protein-reduced diet. GHR protein expression was analysed a second time with a self-made antibody (130 kDa band;
Davids Biotechnology GmbH). Again, a significant decrease in GHR expression was shown due to the protein-reduced diet. The protein expression of INSR was detected as a band of $95 \mathrm{kDa}$, SOCS2 protein expression was detected at $22 \mathrm{kDa}$ and Src protein expression was detected as a band of approximately $60 \mathrm{kDa}$. The protein expression of hepatic INSR, SOCS2 and Src increased significantly due to reduced protein intake. The protein expression of JAK2 was detected at $125 \mathrm{kDa}$. The protein expression of STAT1 was detected at two bands as 84 and $91 \mathrm{kDa}$, STAT3 protein expression was detected as two bands of 78 and $86 \mathrm{kDa}$ and STAT5B protein expression was detected at $90 \mathrm{kDa}$. Protein expression levels of JAK2 and STAT1 did not differ between the two feeding groups. Protein expression levels of STAT3 increased significantly and STAT5B showed an increase by trend due to the protein-reduced diet. Representative Western blots of the investigated proteins are shown in Fig. 3(a)-(1). All data are summarised in Table 9. 
Table 8. Relative amounts of hepatic ALS, ERK2, FGF21, GHR1A, IGF1, IGF2, IGFBP2, IGFBP3, INSR, JAK2, SOCS1, SOCS2, SOCS3, Src, STAT1, STAT3 and STAT5B mRNA expression normalised to hepatic quotient of $18 \mathrm{~S} \mathrm{rRNA} / \beta$-actin in goats fed a protein-reduced diet (Mean values with their standard errors)

\begin{tabular}{llccccc}
\hline & \multicolumn{2}{c}{ Control $(n 8)$} & & \multicolumn{2}{c}{ Reduced protein $(n 9)$} & \\
\cline { 2 - 3 } \cline { 5 - 6 } Items & Mean & SEM & & Mean & SEM & $P$ \\
\hline ALS & $1.98 \times 10^{6}$ & $0.47 \times 10^{6}$ & & $0.68 \times 10^{6}$ & $0.14 \times 10^{6}$ & 0.01 \\
ERK2 & $1.14 \times 10^{-2}$ & $0.05 \times 10^{-2}$ & & $1.10 \times 10^{-2}$ & $0.11 \times 10^{-2}$ & 0.70 \\
FGF21 & $3.47 \times 10^{2}$ & $1.07 \times 10^{2}$ & & $41.76 \times 10^{2}$ & $16.49 \times 10^{2}$ & 0.04 \\
GHR1A & $3.04 \times 10^{7}$ & $0.59 \times 10^{7}$ & & $1.66 \times 10^{7}$ & $0.13 \times 10^{7}$ & 0.03 \\
IGF1 & $2.49 \times 10^{6}$ & $0.51 \times 10^{6}$ & & $1.38 \times 10^{6}$ & $0.20 \times 10^{6}$ & 0.05 \\
IGF2 & $3.83 \times 10^{7}$ & $0.62 \times 10^{7}$ & & $3.03 \times 10^{7}$ & $0.38 \times 10^{7}$ & 0.27 \\
IGFBP2 & $0.13 \times 10^{6}$ & $0.02 \times 10^{6}$ & & $0.40 \times 10^{6}$ & $0.07 \times 10^{6}$ & 0.002 \\
IGFBP3 & $0.11 \times 10^{6}$ & $0.01 \times 10^{6}$ & & $0.11 \times 10^{6}$ & $0.02 \times 10^{6}$ & 0.73 \\
INSR & $0.10 \times 10^{6}$ & $0.02 \times 10^{6}$ & & $0.11 \times 10^{6}$ & $0.01 \times 10^{6}$ & 0.59 \\
JAK2 & $0.37 \times 10^{6}$ & $0.07 \times 10^{6}$ & & $0.40 \times 10^{6}$ & $0.07 \times 10^{6}$ & 0.75 \\
SOCS1 & $0.07 \times 10^{5}$ & $0.01 \times 10^{5}$ & & $0.17 \times 10^{5}$ & $0.09 \times 10^{5}$ & 0.36 \\
SOCS2 & $0.79 \times 10^{6}$ & $0.16 \times 10^{6}$ & & $1.30 \times 10^{6}$ & $0.20 \times 10^{6}$ & 0.08 \\
SOCS3 & $0.07 \times 10^{6}$ & $0.02 \times 10^{6}$ & & $0.14 \times 10^{6}$ & $0.02 \times 10^{6}$ & 0.04 \\
SrC & $6.72 \times 10^{2}$ & $1.14 \times 10^{2}$ & & $9.92 \times 10^{2}$ & $2.14 \times 10^{2}$ & 0.21 \\
STAT1 & $0.17 \times 10^{5}$ & $0.02 \times 10^{5}$ & & $0.17 \times 10^{5}$ & $0.04 \times 10^{5}$ & 0.96 \\
STAT3 & $0.16 \times 10^{5}$ & $0.03 \times 10^{5}$ & & $0.17 \times 10^{5}$ & $0.03 \times 10^{5}$ & 0.84 \\
STAT5B & $1.94 \times 10^{5}$ & $0.49 \times 10^{5}$ & & $1.59 \times 10^{5}$ & $0.37 \times 10^{5}$ & 0.58 \\
\hline
\end{tabular}

ALS, acid-labile subunit; ERK2, extracellular signal-regulated kinase 2; FGF21, fibroblast growth factor 21; GHR1A, growth hormone receptor 1A; IGF1, insulin-like growth factor 1; IGF2, insulin-like growth factor 2, IGFBP2, IGF1 binding-protein 2; IGFBP3, IGF1 binding-protein 3; INSR, insulin receptor; JAK2, Janus kinase 2; SOCS1, suppressor of cytokine signalling 1 ; SOCS2, suppressor of cytokine signalling 2; SOCS3, suppressor of cytokine signalling 3; Src, tyrosine-protein kinase src; STAT1, signal transducers and activators of transcription 1 ; STAT3, signal transducers and activators of transcription 3; STAT5B, signal transducers and activators of transcription 5

\section{Discussion}

The aim of the present study was to determine the influence of a protein-reduced diet on components of the somatotropic axis in young goats. It could be shown for the first time that during growth, this feeding regimen had an impact on parts of the somatotropic axis.

The limitation of the present study was the restricted concentrate feeding instead of ad libitum feeding. Therefore, a potential protein appetite resulting from a stimulation of feed intake and higher body fat which was observed in monogastric species during protein restriction ${ }^{(30)}$ could not be considered. However, in histological tests with liver tissue, no accumulation of fat during a protein restriction could be observed and plasma TAG concentrations remained unchanged.

The hepatic expression of FGF21 mRNA was elevated directly by protein restriction like in mice and rats ${ }^{(19)}$ rather than by energy restriction shown by same BW gain, final weight and unaffected plasma triiodothyronine concentrations, an energydependent indicator which drops due to energy insufficiency ${ }^{(31)}$.

Due to increased IGFBP2 and IGFBP3 protein levels, compensatory mechanisms were presumed to maintain IGF1 availability for the target tissues. In cultured rat hepatocytes, synthesis of IGFBP2, IGFBP3 and IGFBP4 was shown to be affected by insulin and IGF1, whereas a response to GH was not observed $^{(32)}$. Nutritional restriction increased IGFBP2 by an enhanced transcription rate linked to a decreased protein intake $^{(33)}$ as was shown in the present study. As the quotient between IGF1 concentrations and IGFBP3 was significantly reduced due to the low-protein feeding, a decrease in concentrations of free circulating IGF1 was assumed. Unfortunately, immunoassays measuring IGF1 ignore the effects of IGFBPs on the interaction between IGF1 and its receptor ${ }^{(34)}$. Therefore, it would be better to use a method allowing a comparison between serum levels of IGF1 available for its receptor, free IGF1 and total IGF1 ${ }^{(34)}$. Reduced ALS mRNA expression in the animals fed the low-protein diet might lead to higher concentrations of IGF1 bound to the binary complex which is able to pass the vascular epithelium and reach the target tissue. The level of ALS is directly dependent on GH and the regulation occurs at the level of transcriptional activation of the ALS gene in the liver ${ }^{(35)}$. In rat liver, it was found that ALS mRNA and nuclear transcripts were reduced in animals made GH deficient by hypophysectomy. Furthermore, it was shown that GH stimulated ALS promotor activity which was mediated by functional GHR at GH concentrations within the physiological range ${ }^{(35)}$. As GH concentration and pulsatility did not differ between the two groups, a disruption of the somatotropic axis resulting in diminished IGF1 concentrations despite constant levels of GH occurred during a reduced-protein diet.

Unaltered IGF2 mRNA levels support this idea, as GH signalling has only little effect on inducing the IGF2 gene in comparison with the IGF1 gene. As both diets fed in the present study were almost isoenergetic, only a lack of $\mathrm{N}$ intake could cause reduced GHR expression in the present study, which is affirmed by a positive correlation between urea concentrations and GHR expression levels. Interestingly, there is strong evidence that insulin is essential for GH stimulation of hepatic IGF1 production and that insulin regulates hepatic GHR biosynthesis and surface translocation $^{(36)}$. In human hepatic cell lines, the action of insulin on GHR was measured as GH binding to membranes of cells. Additionally, it was shown that insulin increased total GH binding in a concentration-dependent manner by up-regulating receptor biosynthesis ${ }^{(36)}$. Moreover, this former study showed that protein content of JAK2 was not affected by insulin ${ }^{(36)}$, which is in line with our results. In rats, it was shown that the hepatic GHR expression was reduced in the liver of diabetic animals, which could be inverted by insulin therapy ${ }^{(37)}$. In dairy cows, insulin treatment leads to increased GHR and IGF1 mRNA expression levels postpartum and therefore appeared to be a key metabolic signal in linking the GH-IGF1 axis ${ }^{(24)}$. Furthermore, it was shown that reduced serum insulin levels in mice led to lower GHR mRNA levels, indicating that the regulation of GHR expression by insulin is at the transcriptional level ${ }^{(38)}$. With regard to the results of these previous studies, it can be assumed that the modulation of GHR expression was regulated in an insulin-dependent manner in young goats, leading to a disruption of the somatotropic axis. Positive correlation between insulin and GHR expression levels supports this idea.

Hepatic INSR protein expression was significantly enhanced due to the protein-reduced diet, which might be a compensatory mechanism in response to reduced levels of insulin. As mRNA expression levels were unaltered, a translational modification of INSR was assumed. It is known that insulin is able to modulate the level of INSR. In the liver of GHR knock-out mice, the lack of GHR and GH was associated with increased INSR abundance, too ${ }^{(39)}$. It was presumed that this up-regulation was a result of 
(a)

marker $\mathrm{N}+\mathrm{N}-\mathrm{N}+\mathrm{N}-\mathrm{N}+\mathrm{N}-\operatorname{control}^{\mathrm{N}}+\mathrm{N}-\mathrm{N}+\mathrm{N}-\mathrm{N}+\mathrm{N}-$ marker

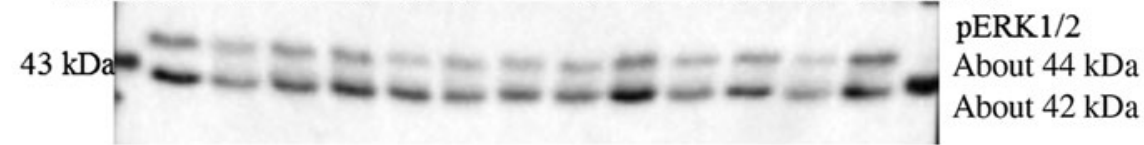

(b)

marker $\mathrm{N}+\mathrm{N}-\mathrm{N}+\mathrm{N}-\mathrm{N}+\mathrm{N}-$ control $^{\mathrm{N}}+\mathrm{N}-\mathrm{N}+\mathrm{N}-\mathrm{N}+\mathrm{N}-$ marker

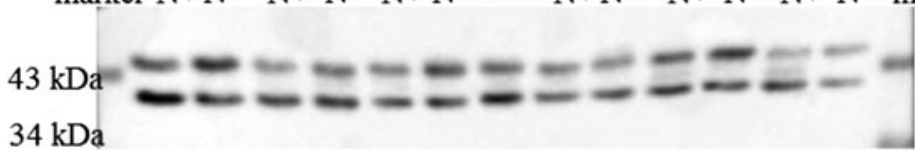

ERK $1 / 2$

About $44 \mathrm{kDa}$

About $42 \mathrm{kDa}$

(c)

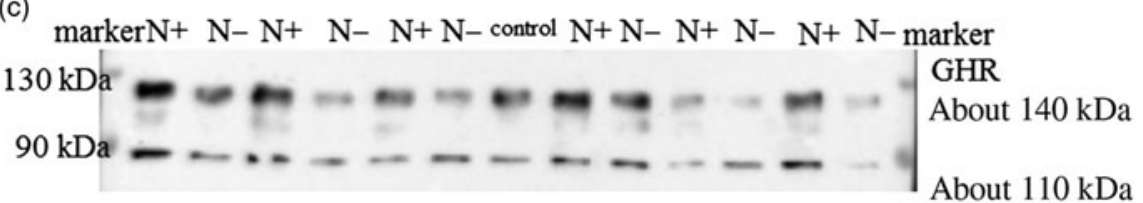

(d)

marker $\mathrm{N}+\mathrm{N}-\mathrm{N}+\mathrm{N}-\mathrm{N}+\mathrm{N}-$ control $\mathrm{N}+\mathrm{N}-\mathrm{N}+\mathrm{N}-\mathrm{N}+\mathrm{N}-$ marker

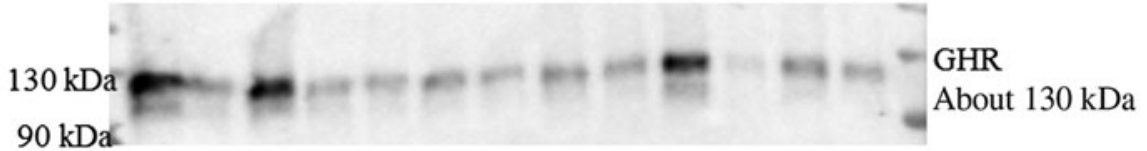

(e)

marker $\mathrm{N}+\mathrm{N}-\mathrm{N}+\mathrm{N}-\mathrm{N}+\mathrm{N}-$ control $\mathrm{N}+\mathrm{N}-\mathrm{N}+\mathrm{N}-\mathrm{N}+\mathrm{N}-$ marker

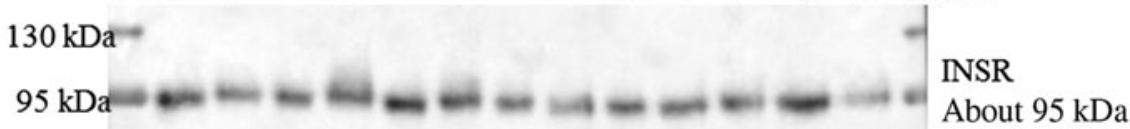

(f)

marker $\mathrm{N}+\mathrm{N}-\mathrm{N}+\mathrm{N}-\mathrm{N}+\mathrm{N}-$ control $^{\mathrm{N}}+\mathrm{N}-\mathrm{N}+\mathrm{N}-\mathrm{N}+\mathrm{N}-$ marker

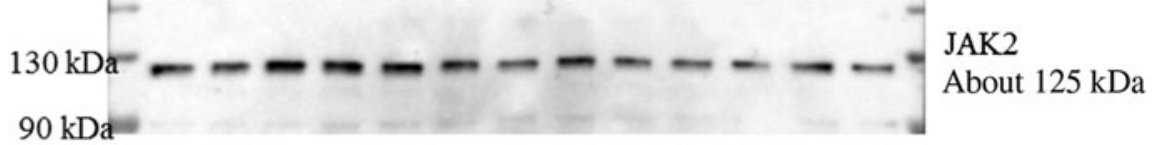

(g)

marker $\mathrm{N}+\mathrm{N}-\mathrm{N}+\mathrm{N}-\mathrm{N}+\mathrm{N}-$ control $\mathrm{N}+\mathrm{N}-\mathrm{N}+\mathrm{N}-\mathrm{N}+\mathrm{N}-$ marker

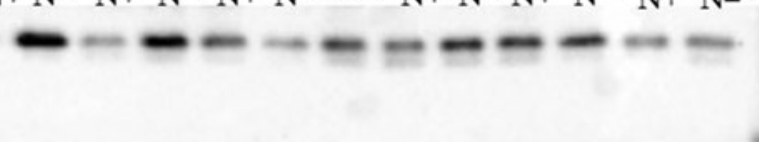

SOCS2

About 22 kDa

$17 \mathrm{kDa}$

(h)

marker $\mathrm{N}+\mathrm{N}-\mathrm{N}+\mathrm{N}-\mathrm{N}+\mathrm{N}-$ control $\mathrm{N}+\mathrm{N}-\mathrm{N}+\mathrm{N}-\mathrm{N}+\mathrm{N}-$ marker

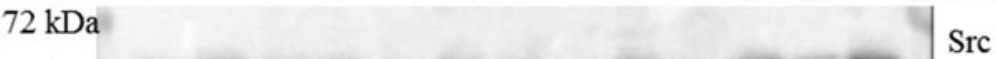

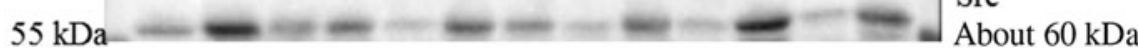

(i)

markeñ $+\mathrm{N}-\mathrm{N}+\mathrm{N}-\mathrm{N}+\mathrm{N}-$ control $\mathrm{N}+\mathrm{N}-\mathrm{N}+\mathrm{N}-\mathrm{N}+\mathrm{N}-$ marker

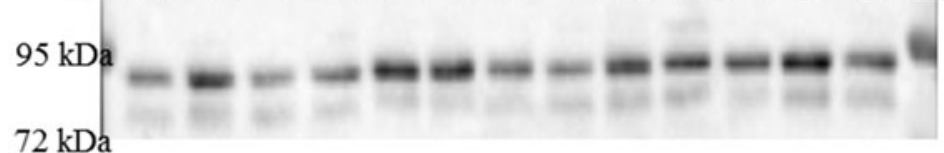

STAT1

About $91 \mathrm{kDa}$

About $84 \mathrm{kDa}$

Fig. 3. Representative signals of phosphorylated extracellular signal-regulated kinase 1/2 (pERK1/2) (a), extracellular signal-regulated kinase 1/2 (ERK1/2) (b), growth hormone receptor (GHR; Santa Cruz) (c), growth hormone receptor (GHR; Davids Biotechnology) (d), insulin receptor (INSR) (e), Janus kinase 2 (JAK2) (f), suppressor of cytokine signalling 2 (SOCS2) (g), tyrosine-protein kinase src (Src) (h), signal transducers and activators of transcription 1 (STAT1) (i), signal transducers and activators of transcription 3 (STAT3) (k) and signal transducers and activators of transcription 5B (STAT5B) (I) protein in hepatic tissue of goats receiving a protein-reduced diet. 
(k)

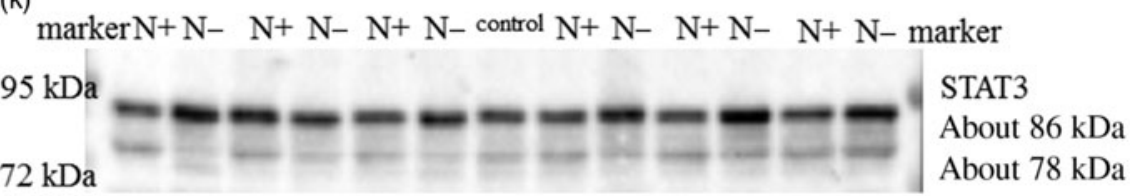

(l)

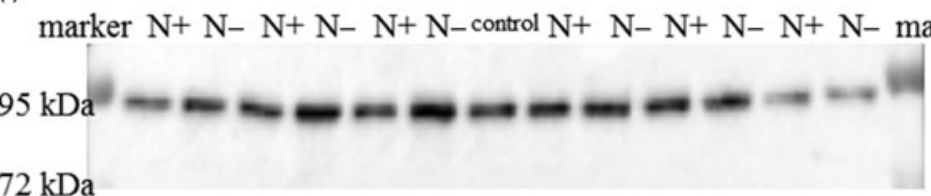

STAT5B

About $90 \mathrm{kDa}$

Fig. 3. (continued)

Table 9. Relative amounts of ERK $1 / 2$ and pERK1/2, GHR, INSR, JAK2, SOCS2, Src, STAT1, STAT3 and STAT5B protein expression normalised to total protein amounts in the liver of goats fed a protein-reduced diet (Mean values with their standard errors)

\begin{tabular}{|c|c|c|c|c|c|}
\hline \multirow[b]{2}{*}{ Item } & \multicolumn{2}{|c|}{ Control (n 8) } & \multicolumn{2}{|c|}{ Reduced protein $(n 9)$} & \multirow[b]{2}{*}{$P$} \\
\hline & Mean & SEM & Mean & SEM & \\
\hline ERK1/2 & $5.07 \times 10^{-3}$ & $0.43 \times 10^{-3}$ & $4.97 \times 10^{-3}$ & $0.47 \times 10^{-3}$ & 0.88 \\
\hline $\mathrm{pERK} 1 / 2$ & $1.59 \times 10^{-3}$ & $0.24 \times 10^{-3}$ & $2.05 \times 10^{-3}$ & $0.35 \times 10^{-3}$ & 0.26 \\
\hline GHR (Santa Cruz) & $3.94 \times 10^{-3}$ & $0.48 \times 10^{-3}$ & $2.13 \times 10^{-3}$ & $0.53 \times 10^{-3}$ & 0.02 \\
\hline GHR (Davids Biotechnology) & $3.46 \times 10^{-3}$ & $0.51 \times 10^{-3}$ & $1.73 \times 10^{-3}$ & $0.57 \times 10^{-3}$ & 0.04 \\
\hline INSR & $0.80 \times 10^{-3}$ & $0.073 \times 10^{-3}$ & $1.07 \times 10^{-3}$ & $0.062 \times 10^{-3}$ & 0.01 \\
\hline JAK2 & $3.55 \times 10^{-3}$ & $0.37 \times 10^{-3}$ & $3.30 \times 10^{-3}$ & $0.25 \times 10^{-3}$ & 0.54 \\
\hline SOCS2 & $1.38 \times 10^{-3}$ & $0.16 \times 10^{-3}$ & $2.51 \times 10^{-3}$ & $0.35 \times 10^{-3}$ & 0.01 \\
\hline Src & $3.68 \times 10^{-3}$ & $0.75 \times 10^{-3}$ & $8.14 \times 10^{-3}$ & $0.73 \times 10^{-3}$ & $<0.001$ \\
\hline STAT1 & $4.84 \times 10^{-3}$ & $0.61 \times 10^{-3}$ & $5.79 \times 10^{-3}$ & $0.38 \times 10^{-3}$ & 0.20 \\
\hline STAT3 & $7.15 \times 10^{-3}$ & $0.56 \times 10^{-3}$ & $9.45 \times 10^{-3}$ & $0.67 \times 10^{-3}$ & 0.005 \\
\hline STAT5B & $1.44 \times 10^{-3}$ & $0.13 \times 10^{-3}$ & $1.90 \times 10^{-3}$ & $0.16 \times 10^{-3}$ & 0.03 \\
\hline
\end{tabular}

ERK1/2, extracellular signal-regulated kinases; GHR, growth hormone receptor 1A; INSR, insulin receptor; JAK2, Janus kinase 2; SOCS2, suppressor of cytokine signalling 2; Src, tyrosine-protein kinase Src; STAT1, signal transducers and activators of transcription 1; STAT3, signal transducers and activators of transcription 3; STAT5B, signal transducers and activators of transcription 5B.

lowered insulin concentrations observed in GHR knock-out mice $^{(39)}$

The decrease in insulin in the present study might be a result of diminished levels of blood Ca because a positive correlation between both parameters exists. Exocytosis of insulin in the pancreatic $\beta$-cells was controlled by $\mathrm{Ca}$, and $\mathrm{Ca}$ channels are linked to insulin secretion ${ }^{(40)}$. It was described that Ca works as a regulator of insulin secretion, acting as a trigger for exocytosis ${ }^{(41)}$. Furthermore, insulin is a key signal of metabolic status ${ }^{(24)}$. As glucose concentrations did not differ between the two feeding groups, a decrease in insulin concentration due to reduced levels of blood Ca seems possible. Additionally, in rats fed a lowprotein diet, the cAMP-dependent protein kinase that is important for insulin secretion in pancreatic $\beta$-cells was decreased ${ }^{(42)}$.

Increased protein expression levels of STAT5B and STAT3 might indicate compensatory mechanisms to maintain IGF1 synthesis. In rats fed a protein-energy malnutrition, IL-activated hepatic JAK2, STAT1 and STAT3 protein were enhanced ${ }^{(43)}$. In a study investigating impaired renal JAK-STAT signalling in chronic kidney disease, it was found that renal GHR expression was reduced and IL-6-mediated SOCS3 and STAT3 expression increased that may affect signalling along the GH-activated JAK-STAT pathway ${ }^{(44)}$. An increase in SOCS2 expression could contribute to diminished IGF1 levels. In line with the results of this previous study, renal GHR expression decreased in our study as well (data not shown). Though JAK2 was thought to be the most important GHR signalling kinase ${ }^{(45)}$, there is strong evidence that in murine pro-myeloid cell lines, activation of the GHR may result in an activation of Src family kinases, leading to activation of ERK1/2 $2^{(46)}$ as an alternative pathway mediating $\mathrm{GH}$ activity. The Src is encoded by a proto-oncogene and activated by phosphorylation ${ }^{(47)}$. In mice with mutations in the JAK2associated motif, it was shown that Src kinase could be activated by GHR independently of JAK2 and that a specific conformational change in the extracellular domain of GHR leads to the ERK1/2 signalling pathway instead of the JAK-STAT pathway $^{(46)}$. Due to the protein-reduced diet, Src protein expression increased, whereas protein expression and phosphorylation of ERK1/2 remained unaltered. In human leukaemia cells, it was demonstrated that GH induced the activation of Src that in turn 
activated STAT5 ${ }^{(48)}$. This might be an explanation for slightly enhanced protein expression levels of STAT5.

Studying the concept of feeding a protein-reduced diet to animals is of interest because in arid or semi-arid regions, feeding an adequate and biologically available protein amount to livestock might be difficult or even impossible due to inadequate substrates that are available in these climatic conditions.

From a broader point of view, the findings of the present study are of importance for humans as well because people in underdeveloped countries of the world might not be able to consume a sufficient amount of dietary protein or supply their children with the recommended amount of dietary protein every day, whereas low-priced carbohydrates are available. Moreover, the reduced intake of dietary protein might occur in the case of vegan cuisine. Here, people might not be aware of replacing animal proteins with plant proteins correctly and therefore enhancing their carbohydrate intake instead of consuming more protein to cover their energy demand.

Besides, for people suffering from kidney diseases, the findings of our study might be of relevance, as they might have to follow a strict low-protein diet for a long time or even for a lifetime. Especially for children who are growing, a reduced protein intake could affect the somatotropic axis through modulated GHR expression levels and therefore development and growth.

In summary, the results of the present study showed that feeding a protein-reduced diet to young goats modulated the somatotropic axis, leading to a reduction in IGF1. While the concentration of GH was not modified, the expression levels of hepatic GHR decreased due to reduced concentrations of insulin occurring in response to low levels of ionised $\mathrm{Ca}$. As GHR is involved in many metabolic pathways, other parts of the body metabolism might be affected by such a diet. Further research is needed to clarify the influence of a protein-reduced diet on the feedback mechanism of the somatotropic axis, giving regard to the relation of reduced levels of IGF1 and hypothalamic hormones.

\section{Acknowledgements}

The authors wish to thank K. Elfers, K. Hustedt and M. Baumgarten for their excellent technical assistance. Moreover, the authors would like to thank F. Sherwood-Brock for proofreading the manuscript. Data of this manuscript is part of the $\mathrm{PhD}$ thesis submitted by Caroline S. Firmenich 2019.

The project was funded by the German Research Foundation (DFG; grant no. Mu 3585/1-3).

A. S. M. conceived and design research; C. S. F., N. S., K. H. and M. S. performed experiments; A. S. M., C. S. F. and M. S. analysed data; A. S. M. and C. S. F. interpreted results of experiments; C. S. F. prepared figures; C. S. F. drafted the manuscript; A. S. M., C. S. F. and M. S. edited and revised the manuscript; A. S. M., C. S. F., N. S., K. H. and M. S. approved the final version of the manuscript.

The authors declare that there are no conflicts of interest.

\section{References}

1. Society of Nutrition Physiology (2003) Recommendations for the Supply of Energy and Nutrients to Goats. The Committee for Requirement Standards of the Society of Nutrient Physiology Report, no. 9. Frankfurt am Main: DLG-Verlag.

2. Muscher AS, Schroder B, Breves G, et al. (2010) Dietary nitrogen reduction enhances urea transport across goat rumen epithelium. J Anim Sci 88, 3390-3398.

3. Harmeyer J \& Martens H (1980) Aspects of urea metabolism in ruminants with reference to the goat. JDairy Sci 63, 1707-1728.

4. Muscher A \& Huber K (2010) Effects of a reduced nitrogen diet on calcitriol levels and calcium metabolism in growing goats. $J$ Steroid Biochem Mol Biol 121, 304-307.

5. Elfers K, Wilkens MR, Breves G, et al. (2015) Modulation of intestinal calcium and phosphate transport in young goats fed a nitrogen- and/or calcium-reduced diet. Br J Nutr $\mathbf{1 1 4}$, 1949-1964.

6. Dubois-Ferriere V, Brennan TC, Dayer R, et al. (2011) Calcitropic hormones and IGF-I are influenced by dietary protein. Endocrinology 152, 1839-1847.

7. Kerstetter JE, O'Brien KO \& Insogna KL (2003) Low protein intake: the impact on calcium and bone homeostasis in humans. J Nutr 133, 855S-861S.

8. Orwoll E, Ware M, Stribrska L, et al. (1992) Effects of dietary protein deficiency on mineral metabolism and bone mineral density. Am J Clin Nutr 56, 314-319.

9. Omdahl JL, Morris HA \& May BK (2002) Hydroxylase enzymes of the vitamin D pathway: expression, function, and regulation. Annu Rev Nutr 22, 139-166.

10. Bianda T, Hussain MA, Glatz Y, et al. (1997) Effects of shortterm insulin-like growth factor-I or growth hormone treatment on bone turnover, renal phosphate reabsorption and 1,25 dihydroxyvitamin $\mathrm{D}_{3}$ production in healthy man. J Intern Med $\mathbf{2 4 1}$, 143-150.

11. Wilkens MR, Elfers K, Schmicke M, et al. (2018) Dietary nitrogen and calcium modulate CYP27B1 expression in young goats. Domest Anim Endocrinol 64, 70-76.

12. Wilkens MR, Firmenich CS, Schnepel N, et al. (2019) A reduced protein diet modulates enzymes of vitamin $\mathrm{D}$ and cholesterol metabolism in young ruminants. J Steroid Biochem Mol Biol 186, 196-202.

13. Kato Y, Murakami Y, Sohmiya M, et al. (2002) Regulation of human growth hormone secretion and its disorders. Intern Med 41, 7-13.

14. Brooks AJ \& Waters MJ (2010) The growth hormone receptor: mechanism of activation and clinical implications. Nat Rev Endocrinol 6, 515-525.

15. Herrington J, Smit LS, Schwartz J, et al. (2000) The role of STAT proteins in growth hormone signaling. Oncogene 19, 25852597.

16. Hansen JA, Lindberg K, Hilton DJ, et al. (1999) Mechanism of inhibition of growth hormone receptor signaling by suppressor of cytokine signaling proteins. Mol Endocrinol 13, 18321843.

17. Duan C \& Xu Q (2005) Roles of insulin-like growth factor (IGF) binding proteins in regulating IGF actions. Gen Comp Endocrinol 142, 44-52.

18. Boisclair YR, Hurst KR, Ueki I, et al. (2000) Regulation and role of the acid-labile subunit of the 150-kilodalton insulin-like growth factor complex in the mouse. Pediatr Nephrol 14, 562-566.

19. Laeger T, Henagan TM, Albarado DC, et al. (2014) FGF21 is an endocrine signal of protein restriction. J Clin Invest 124, 39133922. 
20. Van Soest PJ, Robertson JB \& Lewis BA (1991) Methods for dietary fiber, neutral detergent fiber, and nonstarch polysaccharides in relation to animal nutrition. J Dairy Sci 74, 3583-3597.

21. Sarker PK, Fournier J, Boucher E, et al. (2011) Effects of low phosphorus ingredient combinations on weight gain, apparent digestibility coefficients, non-fecal phosphorus excretion, phosphorus retention and loading of large rainbow trout (Oncorbynchus mykiss). Anim Feed Sci Technol 168, 241-249.

22. Laeger T, Wirthgen E, Piechotta M, et al. (2014) Effects of parturition and feed restriction on concentrations and distribution of the insulin-like growth factor-binding proteins in plasma and cerebrospinal fluid of dairy cows J Dairy Sci 97, 2876-2885.

23. Romeis B (1989) Mikroskopische Technik (Microscopic Technology), 17th revised and expanded ed. Munich: Urban und Schwarzenberg.

24. Butler S, Marr A, Pelton S, et al. (2003) Insulin restores GH responsiveness during lactation-induced negative energy balance in dairy cattle: effects on expression of IGF-I and GH receptor 1A. J Endocrinol 176, 205-217.

25. Elfers K, Breves G \& Muscher-Banse AS (2014) Modulation of aquaporin 2 expression in the kidney of young goats by changes in nitrogen intake. J Comp Physiol B, Biochem Syst Environ Physiol 184, 929-936.

26. Wilkens MR, Kunert-Keil C, Brinkmeier H, et al. (2009) Expression of calcium channel TRPV6 in ovine epithelial tissue. Vet J 182, 294-300.

27. Piechotta M, Kedves K, Araujo MG, et al. (2013) Hepatic mRNA expression of acid labile subunit and deiodinase 1 differs between cows selected for high versus low concentrations of insulin-like growth factor 1 in late pregnancy. J Dairy Sci $\mathbf{9 6}$, 3737-3749.

28. Sacco RE, Nonnecke BJ, Palmer MV, et al. (2012) Differential expression of cytokines in response to respiratory syncytial virus infection of calves with high or low circulating 25-hydroxyvitamin $\mathrm{D}_{3}$. PLOS ONE 7, e33074.

29. Klinger S, Lange P, Brandt E, et al. (2018) Degree of SGLT1 phosphorylation is associated with but does not determine segment-specific glucose transport features in the porcine small intestines. Physiol Rep 6, e13562.

30. White BD, Porter MH \& Martin RJ (2000) Protein selection, food intake, and body composition in response to the amount of dietary protein. Physiol Behav 69, 383-389.

31. Todini L (2007) Thyroid hormones in small ruminants: effects of endogenous, environmental and nutritional factors. Animal 1, 997-1008.

32. Scharf J, Ramadori G, Braulke T, et al. (1996) Synthesis of insulinlike growth factor binding proteins and of the acid-labile subunit in primary cultures of rat hepatocytes, of Kupffer cells, and in cocultures: regulation by insulin, insulinlike growth factor, and growth hormone. Hepatology 23, 818-827.

33. Breier BH (1999) Regulation of protein and energy metabolism by the somatotropic axis. Domest Anim Endocrinol 17, 209-218.
34. Chen JW, Ledet T, Orskov H, et al. (2003) A highly sensitive and specific assay for determination of IGF-I bioactivity in human serum. Am J Physiol Endocrinol Metab 284, E1149-E1155.

35. Ooi GT, Cohen FJ, Tseng LY, et al. (1997) Growth hormone stimulates transcription of the gene encoding the acid-labile subunit (ALS) of the circulating insulin-like growth factorbinding protein complex and ALS promoter activity in rat liver. Mol Endocrinol 11, 997-1007.

36. Leung K-C, Doyle N, Ballesteros M, et al. (2000) Insulin regulation of human hepatic growth hormone receptors: divergent effects on biosynthesis and surface translocation 1. J Clin Endocrinol Metab 85, 4712-4720.

37. Baxter RC, Brown AS \& Turtle JR (1980) Association between serum insulin, serum somatomedin and liver receptors for human growth hormone in streptozotocin diabetes. Horm Metab Res 12, 377-381.

38. Chen N-Y, Chen WY \& Kopchick JJ (1997) Liver and kidney growth hormone $(\mathrm{GH})$ receptors are regulated differently in diabetic $\mathrm{GH}$ and $\mathrm{GH}$ antagonist transgenic mice. Endocrinology 138, 1988-1994.

39. Dominici FP, Arostegui Diaz G, Bartke A, et al. (2000) Compensatory alterations of insulin signal transduction in liver of growth hormone receptor knockout mice. J Endocrinol 166 , 579-590.

40. Rorsman P, Braun M \& Zhang Q (2012) Regulation of calcium in pancreatic alpha- and beta-cells in health and disease. Cell Calcium 51, 300-308.

41. Wollheim CB \& Sharp GW (1981) Regulation of insulin release by calcium. Physiol Rev 61, 914-973.

42. Ferreira F, Barbosa HC, Stoppiglia LF, et al. (2004) Decreased insulin secretion in islets from rats fed a low protein diet is associated with a reduced PKAalpha expression. J Nutr 134, 63-67.

43. Ling PR, Smith RJ, Kie S, et al. (2004) Effects of protein malnutrition on IL-6-mediated signaling in the liver and the systemic acute-phase response in rats. Am J Physiol Regul Integr Comp Physiol 287, R801-R808.

44. Wiezel D, Assadi MH, Landau D, et al. (2014) Impaired renal growth hormone JAK/STAT5 signaling in chronic kidney disease. Nephrol Dial Transplant 29, 791-799.

45. Lanning NJ \& Carter-Su C (2006) Recent advances in growth hormone signaling. Rev Endocr Metab Disord 7, 225-235.

46. Rowlinson SW, Yoshizato H, Barclay JL, et al. (2008) An agonist-induced conformational change in the growth hormone receptor determines the choice of signalling pathway. Nat Cell Biol 10, 740-747.

47. Roskoski R (2004) Src protein-tyrosine kinase structure and regulation. Biochem Biophys Res Com 324, 1155-1164.

48. Manabe N, Kubota Y, Kitanaka A, et al. (2006) Src transduces signaling via Growth Hormone (GH)-activated GH Receptor (GHR) tyrosine-phosphorylating GHR and STAT5 in human leukemia cells. Leuk Res 30, 1391-1398. 